\title{
Entrepreneurship, Microfinance and Social Relation: An Empirical Analysis of Women's Perceptions
}

\author{
Dhaneshwar Rakhal
}

\section{ABSTRACT}

Women can become active entrepreneurs, if they are provided with easy access to the financial services. Microfinance provides access to financial services that can help women to improve their economic life by both promoting opportunities of entrepreneurship and facilitating for the women empowerment. It means microfinance can create opportunities for economic wellbeing, and make them economically independent. Accordingly, this paper explores the women's experiences on microfinance schemes aimed at creating independent women entrepreneurs.

Keywords: Entrepreneurship, microfinance, microenterprise, women, Pokhara

\section{Introduction}

In very business development, credit is an important tool. Absence of credit is a barrier for investment in entrepreneurship activities. Access to credit can increase the adoption of new and more advanced technologies which allow the poor women to expand their enterprises and improve their income level and reduce poverty. Availability of credit increases the level of household's productive and physical assets and also improves the consumption of the poor. Poor women need capital which is held by microfinance providers, as financing to microenterprise in different areas. Credit for small and medium enterprises provides an important tool for the development of industrialization and improving the efficiency of the enterprise and increases productivity (Aftab \& Naveed, 2013). The clients of microfinance banks are mostly self-employed, low income entrepreneurs in urban and rural areas and include traders, subsistence farmers, street vendors, service providers etc.

Women-owned businesses are getting an increasing importance in the economy. The percentage of female business owners in the world has increased day by day. The microcredit industry has also proved on a large scale that women are more trustworthy than men in terms of repayment conduct (Armendáriz \& Morduch, 2000). The demand or need for microfinance comes from the disadvantaged sections of the society who are excluded from the formal sector of financial intermediaries and social networks (Sinha, 2011).

\subsection{Women Entrepreneurship}

Entrepreneurship consists of the opportunity recognition, the process of taking the opportunity, gaining control over the resources, managing the network of resources, and participating in the satisfied fields. Entrepreneurship is the process of creating new ventures, and involves creativity, innovation and risk. It provides options for self employment for an individual and creates employment opportunity for others. It plans, organizes, operates and assumes the risk of new venture. It concerns with innovation, profitability and growth. It is the driving force of economic development of nations. 
(Agrawal, 2012). Sharma and Chrisman (2007) define entrepreneurship as the "acts of organizational creation, renewal, or innovation that occurs within or outside an existing organization" (p. 91).

Basically, entrepreneurshipzhas to do with activities of individual persons. Entrepreneurship is a behavioral characteristic of persons. This behavior has an input and an output side: where on the one hand entrepreneurial behavior requires entrepreneurial skills and qualities, it also implies the participation in the competitive process on the other. In this regards, Wennekers and Thurik (1999) propose the following definition of entrepreneurship:

Entrepreneurship is the manifest ability and willingness of individuals, on their own, in teams, within and outside existing organizations, to perceive and create new economic opportunities (new products, new production methods, new organizational schemes and new product market combinations), and to introduce their ideas in the market, in the face of uncertainty and other obstacles, by making decisions on location, form and the use of resources and institutions (pp. 46-47)

In political economics, entrepreneurship is the quality of being an entrepreneur, i.e. one who undertakes an enterprise (Austin, Stevenson \& Wei-Skillern, 2006). The term puts emphasis on the risk and effort of individuals who own and manage a business, and on the innovations that result from their pursuit of economic success. Entrepreneurs are individuals or groups of individuals, acting independently or as part of a corporate system, who create new organizations, or instigate renewal or innovation within an existing organization (Sharma \& Chrisman, 2007). Similarly, Schumpeter (2011) indicates the functions of entrepreneurs as follows:

... the function of entrepreneurs is to reform or revolutionize the pattern of production by exploiting an invention or, more generally, an untried technological possibility for producing a new commodity or producing an old one in a new way, by opening up a new source of supply of materials or a new outlet for products, by reorganizing an industry and so on (p. 132).

Women are generally less inclined to become entrepreneurs than men and, if they pursue self-employment, they often engage in different activities and start smaller businesses than men. The fact that female entrepreneurs often start smaller businesses than men can be attributed to either different ambitions or activities. Women often engage in the service sector, where businesses tend to be smaller. Moreover, it is often argued that women have less financial resources to invest in the business (Verheul, Wennekers, Audretsch, \& Thurik, 2002). To stimulate entrepreneurship among women and extend their entrepreneurial activities to different sectors of industry, the government can support women by giving advice or financial support.

\subsection{Microfinance}

Microfinance is a tool for providing financial services for the poor. Financial services generally include savings and credit; however, some microfinance organizations also provide insurance and payment services. In addition to financial intermediation, many microfinance institutions provide social intermediation services such as group formation, development of self confidence, and training in financial literacy and management capabilities among member of a group (Acarya, 2009; Bashyal, 2008). Thus the microfinance 
often includes both financial intermediation and social intermediation.

The concept of microfinance came into practice from the establishment of Gramin Bank in Bangladesh in 1970s. And in Nepal, with the establishment of Gramin Bikas Banks (GBBs) in the 1990s, microfinance service began for the poor under the name microfinance. Since then, it has been working in saving and credit, income generating activities, social services targeting rural poor and the women as one of the significant way of empowering women who have been dependent on male on economic activities from the long past (Sharma, 2011). Most of the microfinance programs are focused on women entrepreneurship and empowerment. In this regards, Robinson (2001) defines microfinance as follows:

Microfinance refers to small-scale financial services-primarily credit and savings-provided to people who farm or fish or herd; who operate small enterprises or microenterprises where goods are produced, recycled, repaired, or sold; who provide services; who work for wages or commissions; who gain income from ranting out small amounts of land, vehicles, draft animals, or machinery and tools; and to other individuals and groups at the local levels of developing countries, both rural and urban. Many such households have multiple sources of income (p. 9).

Microfinance is a provision of credit delivery and saving mobilized scheme especially designated to meet the unique financial requirement of the poor. Saving services allow services to store excess liquidity for future use and to obtain returns on their investments. Credit services enable for the use of anticipated income for current investment or consumption. The financing scheme allows the recipients to improve the status of their living through access to additional capital for business activities. The micro financing approach has evolved as an economic development tool intended to benefit low-income women and men including the self employed.

\subsection{Microfinance and Entrepreneurship}

Women-owned businesses are taking an increasing importance in the economy. The percentage of female business owners in the world is increasing day by day. Despite this favorable evolution, access to credit for female entrepreneurs remains a concern for policymakers and researchers. Although women tend to create smaller firms, lack of capital is still a major obstacle to them. Indeed, several studies show that, on average, female entrepreneurs are less financed than male ones. Credit rationing is to be understood here as lower loans granted to women and not higher loan denial like in (Agier \& Szafarz, 2011). Moreover, men and women entrepreneurs differ in at least two respects: women are poorer than men on average, and they have smaller-scope business projects (Morduch, 1999).

By focusing on poor female entrepreneurs in developing countries, microcredit has brought to light the underestimated potential of female self- employment. Within recent times, the relative growth and success of these micro financing initiatives and the socioeconomic impact on marginalized groups in third-world countries have come to the forefront of the development discourse (Esnard-Flavious \& Aziz, 2011). The demand or need for microfinance comes from the disadvantaged sections of the society who are excluded from the formal sector of financial intermediaries and social networks (Sinha, 2011). Therefore, microfinance can play catalyst role in entrepreneurship development for poor women and it can play a key role in income generating activities. 


\subsection{Theoretical link of Microfinance and Entrepreneurship}

The words 'self' and 'subject' are most often used interchangeably. The word subject represents the essence of social, political and cultural engagement of self (Sigalla, 2010). Early modern philosophers, such as Kant and Locke perceived subjectivity as an individual way of thinking (as cited in Sigalla, 2010). Therefore subjectivity is the collection of the perceptions, experiences, expectations, personal or cultural understanding, and beliefs specific to the person. Individual women were incorporated to the practical and efficient system of social regulation and controlled by which it constituted them as subject who in turn became active members in this power relation. Women participate in creating a set of power relations in which they become central of their own subjection. The term subjection in the Foucauldian sense signifies the process of becoming subordinated by power as well as the process of becoming a subject (Sigalla, 2010). Women intend to repeat a particular kind of freedom (which the ability to assume control for one's own management), the kind of women (who takes personal responsibility) and the kind of relation (the lender-the borrower) that the dominant paradigm. Critical to this process is its ability to enlist individual subjects into entrepreneurialism and its related subjective modalities.

Neoliberalism, according to Foucault, extends the process of making economic activity a general matrix of social and political relations, but it takes as its focus not exchange but competition. What the two forms of liberalism, the "classical" and "neo" share, according to Foucault, is a general idea of "homo economicus," that is, the way in which they place a particular "anthropology" of man as an economic subject at the basis of politics. Competition necessitates a constant intervention on the part of the state, not on the market, but on the conditions of the market. As Foucault writes cited in Read (2009) summarizing this point of view: "Homo economicus is an entrepreneur, an entrepreneur of himself" (p. 28). Therefore, the focus on income generation, self-employment, and the encouragement of developmentalist subjectivities is a consistent theme in the microcredit approach to develop micro entrepreneurs. Here the entrepreneurial subjectivity is elevated above other subjective modalities that the individuals, or the targets of microcredit programs, may already be living to take up. Yunus goes so far as to link credit with the discursive model of liberal Western subjectification-the notion of human rights (Brigg, 2001).

Fernando cited and argued that women's position in the liberal phase of capitalist expansion has been shaped by three overlapping problems. First, they were seen as an under tapped resource (labor and consumer) that needed to be addressed in relation to the reproductive needs of the neoliberal economy. Second, gender relations needed to be configured in ways that could allow the expansionary needs of capitalism. Third, gender inequalities appeared simultaneously as barriers to overcome and an opportunity for the expansion of surplus value. Social programs, such as microcredit for economic development, had to be designed to address these concerns. Microcredit schemes, therefore, appeared as an effective tool to achieve the wider goal of growth. In many contexts, though, microcredit schemes have been presented to women as a panacea; in freeing them from the bondages of exploitation. Such schemes, therefore, gained enormous popularity across the 'developing' world. In this way individual women become involved in achieving much wider goals (Sigalla, 2010). Through such social programs, it was therefore possible to govern individual subjects. 


\section{Problems and Objectives}

The above literature showed that the microfinance program could lead to women entrepreneurship. Hence an attempt has been made to analyze the impact of microfinance on women entrepreneurship. So, the specific objectives of the study are to assess the influence of microfinance access on entrepreneurship, and to explore the women's social relation changed after joining the entrepreneurial activities.

\section{Data and Menthods}

The study is descriptive in nature and based on the data obtained through semi-structured interviews. The qualitative research design is used that intends to describe both process and outcomes of the participants' experiences. Women with varied of experiences, different types and sizes of business, and grounds in different communities, those who are interested to give interview, are selected for interview. Sample included women living in Pokhara valley. The study criteria also focused on women who had joined microfinance schemes at least five year before. By applying these criteria, twelve women were selected purposively for detailed interview. Transcripts from the interview record were made in Nepali language and studied, marked and labeled. Then, responses were grouped according to subjects or theme; then analyzed.

\section{Discussion and Analysis}

\subsection{Access to Microfinance and Development of Micro Enterprises}

Do microfinance support to the entrepreneurial activities of women? The analysis of interview data indicates participation in microfinance program increases women's entrepreneurial activities. The main entrepreneurial activities or business of the interviewees are tailoring, photo studio and video mixing, electronics and mobile repairing, buffalos and cows keeping, grocery and tea shop, restaurant, embroidery shop, cosmetics. Most women invested loan in business for income generation. One of these women exposed:

.... I contacted to microfinance group and join for the loan to do business twenty years before. I took the first loan, Rs 8000 from microfinance institution and started small hotel near the film hall in Pokhara. Then I repeated and increased loan many times.

(Forty one years old Magar woman)

Another revealed:

At first, I received ten thousand rupees' loan easily. Other four members agreed to provide loan for me. That amount was very large to me ten years ago.... Now I have taken Rs 90,000 at 20 percent interest rate.... The loan is invested in business. At the beginning, we opened watch repairing shop. Then we started electronic shop. Now mobile repairing and electronics shop since five years.

(Thirty one years old Islam woman) 
Micro loan is used as capital investment also. Some women purchased fixed assets from this loan. The data indicates that microenterprise activities can access the educational opportunity for the children of the clients. The study of lzugbara (2004) also shows that the household of those women in microcredit schemes had more children in school. In this connection one woman said:

.... I pay creditors of clothes and sewing materials. Again I purchase cloths for business. Sometimes I purchase new machine also. I have earned from that money (loan). Tailoring is main income source. There is no other income source.... I pay for household expenditure.... I pay for school fee and other expenses of five children from the income of this business. You know, I have five children. I have managed for education of five children from tailoring.

(Forty seven years old Pariyar woman)

Data also shows that the majority of respondents, that is, eight women had already established their small business enterprise before to their participation in microfinance program. Most of them used micro loan to sustain and expand their existing micro enterprises. Some of the micro loan users express:

...I had small vegetables shop. There was no other alternative. I needed amount for additional fruits for business expansion in the occasion of dashain festival. At that time, I received ten thousands rupees from bank as loan for oneyear term.... After a year, I ran grocery shop and became gas dealer for some times.... Then I started cow and buffalos farming.

(Thirty five years old Brahmin woman)

Another woman adds:

.... So we started business. We needed money for business expansion. Therefore, I had taken loan from this institution Rs10000 at first. Now I have taken loan Rs40000.... That loan helped my business. I repay loan from my business income.

(Thirty seven years old Newar woman)

The loan provided from microfinance institution is not sufficient for business run as well as expansion of business. Therefore, participants' women sometimes search other sources of loan. One of them responded:

But this amount is not sufficient for my business. I have taken additional loan from merchant at 36 percent interest rate...

(Thirty one years old Islam woman)

The data also indicates that large family size affects the entrepreneurial activities negatively. If family size of micro entrepreneur is large, he/she couldn't use loan properly. Consequently, those types of conditions compel the clients into debt trap. One woman exposed:

.... I gave birth to seven children regularly. There was a problem to bring up children.... For the alternative sources of income, I joined microfinance group 
nineteen years ago. I took Rs 8000 initial loan, and some part of this loan was used to pay previous loan and some was used for household expenses. By using residual amount of loan, I started cloth business as a travelling trader.... Gradually I had taken this loan many times and loan volume increased up to Rs 600000 . After that, I have taken micro loan from other financial institutions also. I have taken loan from NESDO, DEPROSC Microfinance Development Bank, Muktinath Development Bank, Srijana Community Development Center, Mothers Group and local merchant. Most of these loans have been used for the payment of previous loan and day to day expenses.

(Forty years old Magar woman)

Proper family supports are the most important factor of entrepreneurship development of women. Without family support micro loan cannot be utilized appropriately in income generating activities. About income generating activities one woman said:

.... I had no hand to mouth way even on delivery time. He only drank. I needed money but I had no idea. With the help of my friend Laxmi, I joined in microfinance group and I took initial loan Rs 8000 and started vegetable selling. I increased loan gradually.... Instead of receiving help, my husband only disturbed me and my business.... I could not continue my business... Now I am doing cleaning job in film hall and living alone in a rented room.

(Fifty years old Newar woman)

\subsection{Microenterprises and Social Relation}

Six women responded that there is no change in social relations because of the involvement in microfinance program. The members who are from high economic classes as compared to other members think so. Members, who really benefitted from micro loan and started small business, have different experiences. Out of twelve women, four women felt that the social relation is improved after starting the microenterprises. At the initial phase, one woman was a group head and now she is a center head. I asked her 'how do you find about the changes in social relation after joining microfinance?' She replies:

Before being center head, we were the members of similar categories. Now, I am a center head and the situation is different. I am respected by other person.

(Thirty one years old Islam woman)

Another said:

The perspectives of neighbors and relatives towards me are positive. They say 'The woman is capable, she can live herself'...

(Thirty years old Brahmin woman)

And yet another:

.... bank's staffs treat me as friends. If I need loan, I can receive immediately. Even, I did not take help from my parental house when I got difficulty.

(Forty eight years old Gurung woman) 
It is found that some participant women felt bad social relation because of their husband's habit. Out of twelve participants, three women were divorced from their husbands due to their misbehavior. One woman thinks her social relation is not so good after joining the program. She said:

...Because of the habit of my husband, my relation to neighbor is spoiled...but my brother in law (dewar) is helping me. I have not gone to my relatives.

(Forty one years old Magar woman)

Another also said:

.... I have not gone parental home. I do not go to my relatives. Some of them advise me to go there. But I feel uneasy. So do not go there.... I am weeping many times to remember that.

(Fifty years old Newar woman)

\section{Findings}

There is no doubt that most of women (nine women) want to be entrepreneurs in current situation. They use micro loan properly in business or income generation activities. But some (three women) of them could not use financial resources properly and 'poorest' become worse. This observation correlates that of Sigalla (2010) in Tazania where they observed that such schemes benefited households which were just below the poverty line more than those which were far below it, and that the households which were 'poor' and in some cases been made worse. It indicates that the microcredit schemes have been, however, linked to capitalists' efforts to search for new approaches to advance the liberal ideology of private entrepreneurship.

Both women and men expected gender roles and responsibilities in society rather than transforming existing structural inequalities. In order to say in good standing with microfinance program and their solidarity group, women (like forty years old Magar women) decided to borrow money from a different microcredit program in order to survive their current loans because she is in debt trap. She decided to go to another institution to borrow money in order to settle the current loan. In doing so, she now has tied herself further to regulatory forms of microcredit and its powerful mechanisms of self governance.

The involvement of different organization indicates that women are able to occupy new subject positions, though, in varying contexts. For example, the data indicates the social relation of three women was improved and builds up self-confidence. Through microcredit, women are able to expand their traditional roles as a woman to incorporate entrepreneurship.

\section{Conclusions and Recommendations}

From this study, it is found that majority of women are running income generating activities. The access of loan to the poor women is essential for income generation through entrepreneurship. Microfinance provides access to financial services that can help to decrease poverty by promoting opportunities in financial access to the poor including women. Therefore, microfinance program has improved the life of many poor 
through income generating activities. This study also points out that the credit access to women not only improves the economic condition of the family but also increases the social relations. Therefore, microcredit schemes have been linked to capitalists' efforts to search for new approaches to advance the liberal ideology of private entrepreneurship, capitalism and social mobilization based on multiple social identities.

However, there are some problems for entrepreneurship as the interviewees have felt, there is no proper support from the family; they are not provided additional loan for the women in difficult conditions etc. Income generating activities of the member can be affected and their business may get failure, because of such problems. Therefore, flexible policy should be formulated to assist poor women in cases of business failure. Many poor women can became active entrepreneurs, if their entrepreneurship is developed through positive strengthening and supporting for the financial access.

\section{BIBLIOGRAPHY}

Acharya, Y. P. (2009). Understanding sustainable microfinance and poverty alleviation of farmers' in rural Nepal. New Delhi: Adarsh Books.

Aftab, M., \& Naveed, T. A. (2013). Role of microfinance institutions in entrepreneurship development in District Gujrat, Pakistan. J. Glob. \& Sci. Issues, I(1), 53-69.

Agier, I., \& Szafarz, A. (2011). Credit to women entrepreneurs: The curse of the trust worthier. Brussels: Université Libre de Bruxelles

Agrawal, G. R. (2012). Entrepreneurship development in Nepal. Kathmandu: M. K. Publishers and Distributors.

Armendáriz, B., \& Morduch, J. (2000). Micro finance Beyond Group Lending. Economics of Transition, 8(2), 40-420.

Austin, J., Stevenson, H., \& Wei-Skillern, J. (2006). Social and commercial entrepreneurship: same, different, or both? Entrepreneurship theory and practice, 30(1), 1-22.

Bashyal, R. (2008). Microfinance: Access to finance for Nepal's poor. Kathmandu: Institute for Integrated Development Studies.

Brigg, M. (2001). Empowring NGOs: the microcredit movement through Foucault's notion of dispositif. Alternatives: Global, Local, Political, 26(3), 333-258.

Esnard-Flavious, T., \& Aziz, Z. (2011). Microcredit, microenterprises and social welfare of the rural poor in North-Eastern Trinidad: An evaluation of "HOPE". Asian Academy of Management Journal, 16(1), 95-118.

Izugbara, C. O. (2004). Gendered micro lending schemes and sustainable women's empowerment in Nigeria. Community Development Journal, 39(1), 72-84.

Morduch, J. (1999). The microfinance promise. Journal of Economic Literature,37(4), $1569-1614$.

Read, J. (2009). A genealogy of homo-economicus: Neoliberalism and the production of subjectivity. Foucault Studies, 6, 25-36. 
Robinson, M. S. (2001). The Microfinance revolution: Sustainable finance for the poor. Washington, DC: The World Bank.

Schumpeter, J. A. (2011). Capitalism, socialism and democracy. New Delhi: Adarsh Book.

Sharma, P., \& Chrisman, S. J. (2007). Toward a reconciliation of the definitional issues in the field of corporate entrepreneurship. In Á. Cuervo, D. Ribeiro, \& S. Roig (Eds.), Entrepreneurship (PP. 83-104). Berlin: Springer.

Sharma, P. R. (2011). Impact of microfinance on women empowerment. Pokhara: Team Organizing Local Institution (TOLI).

Sigalla, R. J. (2010). Women's identities, learning and microcredit in Tanzania. Unpublished doctoral dissertation in education. Roskidle University, Denmark.

Sinha, G. K. (2011). Social exclusion, poverty and microfinance. Economic Affairs, 56(2), $129-131$.

Verheul, I., Wennekers, S.,Audretsch, D., \& Thurik, R. (2002). An eclectic theory of entrepreneurship: policies, institutions and culture. In D.Audretsch, R. Thurik, I. Verheul, \& S. Wennekers (Eds.), Entrepreneurship: Determinants and policy in a European-US comparison, (PP. 11-81). New York: Kluwer Academic Publishers

Wennekers, S., \& Thurik, R. (1999). Linking entrepreneurship and economic growth. Small Business Economics, 13(1), 27-56. 